Universities the pattern is almost invariably the same-unbalanced development as between faculties ; salaries that are too low to attract overseas lecturers or to hold Australian staffs; inadequate teaching facilities ; overworked staff who, in trying to maintain standards, have been preoccupied with teaching and administrative duties to the detriment of research; inadequate research facilities ; repairs to buildings and plant that have to be deferred; and a deficit that somehow has to be met".

The vice-chancellors pointed out that up to that time the universities had been able to maintain their teaching standards, in spite of the tremendous problems caused by the doubling of student numbers after the War. But this had only been possible because of constant overwork and improvisation on the part of teaching staffs, and it was suggested that if no relief were afforded soon an appreciable lowering of standards would be inevitable. To provide the necessary relief the financial resources of the universities would have to be increased substantially.

This was the background against which the Commonwealth Government, early in 1950, had appointed a committee to inquire into the needs of Australian universities. The terms of reference of this committee were : to examine and report upon the finances of universities, having regard to their facilities for teaching and research, including staff, buildings and equipment; to examine and report upon the requirements of universities in relation to the work at present undertaken and to the need for their future development; and to make recommendations as to whether any, and if so what, action should be taken by the Commonwealth to assist the universities. The committee of inquiry is still considering the long-range developmental needs of the universities, but has submitted an interim report with recommendations designed to get the universities over their immediate financial difficulties.

On the basis of this report the Commonwealth Government has made an offer to the State Governments to provide financial assistance for their universities. Section 96 of the Commonwealth Constitution permits the Commonwealth Parliament to grant financial assistance to the States on such terms and conditions as it thinks fit. The State Governments have been traditionally regarded as responsible for the universities, and this principle has been preserved in the Commonwealth offer, the details of which are as follows.

(1) The present Commonwealth Reconstruction Training Scheme subsidies and the Commonwealth grant for research and research training in the physical, biological and social sciences (which together would have amounted to about $£ 450,000$ in 1950) will be replaced by a grant of $£ 803,000$ a year, including $£ 25,000$ for residential colleges. This grant will be allocated among the State universities in accordance with relative numbers of students (with special weighting for smaller universities) and will be made for each of three years from January 1 , 1951. Before any university can qualify for this 'basic' grant, however, its State Government grants, plus fees, must reach a level at least three times the amount of the proposed Commonwealth grant. No restrictions have been placed upon the use of the Commonwealth grants, except a proviso that they shall not be applied towards capital extensions.

(2) To encourage State Governments to raise their grants, the Commonwealth will make a 'second-level' grant of $£ 1$ for every $£ 3$ by which State grants and fees exceed the amount necessary to enable the university to qualify for the basic grant (up to a limit of $£ 300,000$ a year spread over all the universities).

(3) If agreement with the States can be reached quickly enough, the Commonwealth offer will be back-dated to July 1, 1950, so as to enable the universities to receive $£ 351,500$ for the last six months of 1950 in place of the $£ 225,000$ (approximately) that they would have received under subsidies and the research grant of the Commonwealth Reconstruction Training Scheme.

If this offer is accepted by the State Governments, the immediate financial difficulties of the universities will be eased quite considerably. Altogether the universities might receive about an additional $£ 1,000,000$ in revenue in 1951 compared with 1950 . This would be made up of about $£ 425,000$ additional Commonwealth assistance, about $£ 225,000$ increased fees and about $£ 350,000$ additional State grants needed to enable the universities to qualify for the larger Commonwealth grant.

About one-third of this new money will, in fact, be absorbed in covering 1950 deficits, and about half will be spent in paying long-overdue salary increases and increases that have already occurred in wages and other costs. There will thus be little left to provide for the new activities necessary if the universities are to develop at a satisfactory rate.

At a later meeting of the Australian Vice-Chancellors' Committee, in March this year, it was pointed out that the additional financial assistance would prevent further immediate deterioration in the position of the universities, but would not enable them to embark on forward-looking development. While the universities themselves are particularly anxious that the State Governments should maintain primary responsibility for their universities, the only hope of substantial university development from their present retarded position lies with the Commonwealth Government. For this reason, the long-term inquiry being made by the Commonwealth committee, to which reference has already been made in this article, has vital significance for the universities of Australia.

\section{INSTITUTE OF JUTE TECHNOLOGY, CALCUTTA}

HE traditional textile industries have always retained an element of craftsmanship in many of their technological processes, and experience, acquired in the hard way by trial and error in the mills, must still remain an important factor in the qualifications of an efficient operative. Nowadays, however, under the stimulus of competition, actual or potential, from the more modern processes of synthetic and rege nerated fibres, the older industries which exploit the natural fibres have found it necessary to make more and more use of the results of the extensive research on fibres and fibre processing which has been carried out during the past thirty years; and the demand for an education with a scientific background, which will enable the higher grades of workmen to cope with the new situation thus brought about, has shown a steady rise. In Great Britain and the industrial West generally, there has been available a welldeveloped system of technical colleges and university departments adapted to deal with this demand at all lovels. 
Although the technical colleges have their place in the structural scheme of Indian education and have, in fact, included courses in textile technology in their curricula, the emphasis in India has in the past been placed almost entirely on cotton, to the exclusion of jute. The reason for this discrimination appears to have arisen from the traditional attitude of the jute mills, for the most part financed and managed by the British, towards the recruitment of men to fill the more responsible supervisory posts ; until fairly recently the tendency was to import British-trained men, and there was consequently less demand by Indians for training in jute than in cotton technology. This attitude has had to be revised, however, because of the altered political and economic circumstances, and the industry is faced with the problem of finding suitably trained men for entry into the mills as supervisors.

The foundation of the Institute of Jute Technology in Calcutta is an attempt to solve this problem by providing a course of instruction, spread over three years, for 100-150 student-apprentices. To qualify for entry, candidates must have passed the equivalent of the intermediate science examination, to have reached, that is, the minimum standard for entry on a university degree course. The subjects studied at the Institute include the basic sciences-mathematics (including elementary statistics), physics, and chemistry - the production and characteristics of the vegetable fibres generally, the spinning and weaving of jute, analysis and testing, engineering and machine drawing, and business organization and administration. Besides this, about half the duration of the course will be spent in mills acquiring practical experience of the industry. Entrance is restricted to nominees of the mills, which pay the tuition fees and make a subsistence allowance to their nominees.

At present the full-time staff consists of the principal, three senior lecturers (engineering, physics and testing, and spinning and weaving) and a lecturer in textile chemistry; part-time lecturers deal with jute production and business organization, etc. The principal, C. R. Nodder, was formerly ehief chemist to the Linen Industry Research Association in Belfast, and later director of the Technological Research Laboratories of the Indian Central Jute Committee.

The Institute was formally opened early in March by Dr. B. C. Roy, Chief Minister, West Bengal. The buildings, which were started in 1948, consist of two blocks : one, intended to house technological equipment, is not yet completed ; the other, containing administrative offices, an assembly hall, common room, refectory, lecture rooms, laboratories and library, is already in use by the first batch of students. The buildings stand on about $1 \frac{1}{3}$ acres of land. The estimated capital outlay, Rs. 2,000,000, and the provision of an annugl running expenditure of Rs. 200,000, have been made by the Indian Jute Mills Association. The Institute is to be affiliated to the University of Calcutta and is to be administered jointly by the University and the Indian Jute. Mills Association; the University has not, however, been called upon to shoulder any financial burden, although, in fact, the assets of the Institute are to be vested in it by a deed of trust.

From the point of view of the Institute, affiliation to the University, if it implies opportunities for students to share in non-academic activities (it is not elear at present whether this is, in fact, the intention), is an obvious advantage, as it would afford a possible counterpoise to the bias imposed by the restriction of the declared activities of the Institute to teaching. If it is the intention that students may ultimately graduate from supervisors to managers, some contact with active research is probably desirable. One obvious development along these lines suggests itself: the Indian Jute Mills Association already has a Research Institute in Calcutta, with a scientific staff in contact with both fundamental and processing research, and some sort of collaboration between the two Institutes, perhaps by means of colloquia in which selected current research topics could be discussed, could do much to help train the students as possible liaison men between the new Institute and their mills.

\section{FIFTY YEARS OF SYSTEMATIC SEROLOGY}

\section{NUTTALL MEMORIAL CELEBRATION}

7 HIS year may be said to mark the end of the first half-century of systematic serology, for it was in 1901 that the late Prof. G. H. F. Nuttall, emeritus professor of biology in the University of Cambridge, published the first reports describing the results of the testing of precipitin antisera with a variety of antigens of animal origin, and thereby started the science of comparative or systematic serology. In recognition of this anniversary, a Nuttall memorial celebration was held on March 19 at the Serological Museum of Rutgers University; during the afternoon there was an exhibition of the work of the Museum and of its Nuttall historical materials, and a tea for serologists and friends of the Museum. The materials exhibited included some of Nuttall's original fluid sera, four of his charts, and two sets of protocols relating to the researches in blood relationship, all of which had previously been in the care of Prof. D. Keilin, director of the Molteno Institute in the University of Cambridge, and were given to Dr. Alan Boyden, director of the Serological Museum, during the latter's visits to Cambridge last August.

The celebration was concluded with a symposium in the evening, sponsored by the Rutgers Chapter of Sigma $\mathrm{X} i$, entitled "A Half-Century of Systematic Serology; the Work of Nuttall and his Associates at Cambridge and of his Successors in America". Those participating were: Dr. T. C. Nelson, who gave an account of Nuttall based on his visits to Nuttall's laboratory and home in 1931; Dr. P. A. Moody, who reported on researches in systematic serology carried on in the University of Vermont under his direction; and Dr. Alan Boyden, who briefly summarized the more important old and new work in the field and gave an appraisal of the sig. nificance of Nuttall's contribution to it.

Dr. Boyden pointed out that Nuttall himself was aware of some of the limitations of his techniques. In 1902, after completing a series of quantitative tests in which he measured the volumes of settled precipitates, Nuttall said: "I do not wish these numbers to be taken as final, nevertheless they show the essential correctness of the previous crude results. To obtain a constant it will be necessary to make repeated tests with the bloods of each species and with different antiserums of one kind, making the tests with different proportions of antiserum. I am inclined to believe that with care we shall perhaps be able to measure species by this method, for 